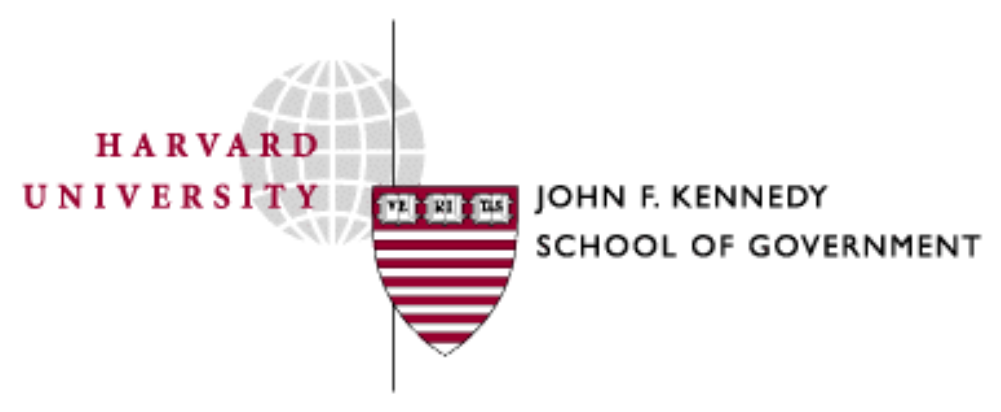

Faculty Research Working Papers Series

\title{
Caste Embeddedness and Microfinance: Savings and Credit Cooperatives in Andhra Pradesh, India
}

\author{
Guy Stuart \\ John F. Kennedy School of Government - Harvard University
}

September 2006

RWP06-037

This paper can be downloaded without charge from:

http://ksgnotes1.harvard.edu/Research/wpaper.nsf/rwp/RWP06-037

or

The Social Science Research Network:

http://ssrn.com/abstract=902388

The views expressed in the KSG Faculty Research Working Paper Series are those of the author(s) and do not necessarily reflect those of the John F. Kennedy School of Government or Harvard University. Copyright belongs to the author(s). Papers may be downloaded for personal use only. 


\title{
Caste Embeddedness and Microfinance: Savings and
}

\section{Credit Cooperatives in Andhra Pradesh, India}

\section{Guy Stuart}

\author{
Associate Professor \\ Kennedy School of Government, Harvard University \\ 79 JFK Street \\ Cambridge, MA 02138 \\ guy_stuart@harvard.edu
}

Tel: 617-496-0100

Fax: 617-495-1722

This paper would not have been possible without the field work of Sandhya Kanneganti who is a development consultant based in Andhra Pradesh, and is on the board of directors of the Cooperative Development Foundation (CDF) in Hyderabad. At the time when she was conducting field research for this study, in July and August 2001, she had no formal relationship with the CDF. I also wish to thank the Cooperative Development Foundation for their willingness to share their knowledge about the cooperatives with me. Particular thanks go to Rama Reddy, Uma Devi, and Vijaya Lakshmi. 


\section{Abstract}

This paper examines how the introduction of a new set of institutional practices through the creation of new organizations bump up against, but also build on, the existing social structure and practices of the setting in which they are introduced. In this case, the new practices were cooperative governance and financial accounting practices introduced through the medium of cooperative organizations into villages in Andhra Pradesh, by the Cooperative Development Foundation (CDF) during the 1990s. The paper demonstrates how the CDF both built on and challenged the existing social structure of the villages in which their cooperatives developed. In particular, the paper shows that the new institutional rules the cooperatives implemented interacted with the existing caste and gender structure in a variety of ways that included direct conflict, mutual support, and indifference. 


\section{Introduction}

The Cooperative Development Foundation, headquartered in Warangal in the state of Andhra Pradesh in India, helped launch its first women's thrift cooperative in 1990. As of the end of 2004, there were 256 women's thrift cooperatives in the Karimnagar and Warangal districts of Andhra Pradesh with a total of about 70,000 members (Cooperative Development Foundation, 2004). These cooperatives were organized into 27 associations of women's cooperatives (AWTCs) ${ }^{1}$.

This paper examines how the introduction of a new set of institutional practices through the creation of new organizations bump up against, but also build on, the existing social structure and practices of the setting in which they are introduced. In this case, the new practices were the rules of cooperative governance and techniques for providing financial services to poor; the existing social structure was a set of villages in rural Andhra Pradesh, with strong caste and gender divisions among others. The paper demonstrates the ways in which people embedded in an existing social structure adapt and adapt to the new institutions that accompany a new organization promoted from outside, in ways that are presaged but not wholly determined by what was there before. Embeddedness turns out to play a varied role as both a foundation on which the new organization is built and a constraint on its transformative possibilities.

\footnotetext{
${ }^{1}$ There were also 159 men's thrift cooperatives organized into 21 associations.
} 


\section{Embeddedness}

In the overlapping literatures on social capital and economic development, on the one hand, and the "new economic sociology," on the other, the concept of embeddedness is central. $^{2}$ The concept of embeddedness begins with the observation that almost all people are in engaged in more than one sphere of activities, for example economic activities, social activities, and political activities, and within those spheres there are sub-spheres of activities. The extent of embeddedness is the extent to which the way a person thinks and acts in one sphere, and the social structures that inform those thoughts and actions in that sphere, have consequences for how she can and does think or act in another sphere. Embeddedness is commonly defined in terms of either networks or institutions, where networks are social relations between people that are maintained over time, while institutions are persistent formal and informal rules of practice and ways of thinking about the world that are enforced through sanctions and rewards (Jepperson 1991, 145; Fligstein 2001, 11).

\footnotetext{
${ }^{2}$ Depending on where one draws certain intellectual lines of separation, those working in the field of the "new economic sociology" are either in the thick of studies of social capital (Woolcock 1998, 155), or have a more tangential relationship to it - tangential in that they use the term "social capital" as a convenient shorthand but use different concepts that might be considered the building blocks of social capital. The clearest point of intersection is Granovetter's (1985) concept of embeddedness, because of his central role in the field of economic sociology and the fact that the concept is central to both that field and to most definitions of social capital.
} 
Granovetter defines embeddedness in terms of "concrete personal relations and structures (or "networks") of such relations" $(1985,490)$. His is a network definition of embeddedness, in which what "constrain[s]" individual behavior and institutions is "ongoing social relations" (ibid., 482). Grano vetter explicitly rejects the role of institutions as effective constraints on unwanted behavior (ibid., 490) Furthermore, he describes the social construction of economic institutions in terms of agglomerations of social relations (Granovetter, 1992). Putnam (1993) describes social capital as "norms of reciprocity and networks of civic engagement." (ibid., 167) For Putnam the importance of networks of civic engagement are that they embed people in relationships that affect how they relate to the same people in other spheres of activity. And norms of reciprocity seem to be a general, taken-for-granted expectation that exists in a society that an individual will reciprocate when someone else acts in ways that benefits that individual. In other words, norms of reciprocity constitute an informal institution that promotes and is maintained by trusting working relationships between individuals. So, in this case, institutions and networks are closely related in that the former enable the development of the latter by making it easier for people to trust each other.

Granovetter and Putnam both focus on networks as the prime site of embeddedness, with institutions playing a minor or supporting role, respectively. But others have sought to establish networks and institutions as independent and equally important sites of embeddedness. ${ }^{3}$ Fligstein (2001) argues that there are "two types of social relations

\footnotetext{
${ }^{3}$ The phrases "institutional embeddedness" and "network embeddedness" are common in the literature, and Swedberg (2004) argues that there are a number of different types of embeddedness -- political, cultural,
} 
scholars use to understand how markets work. First, there are the actual relationships among producers, consumers, suppliers, and governments in a given market... Second, societies have general rules, both formal and informal, about organizing economic activities." (ibid. 10-11). Woolcock, in developing his "synergy view" of social capital attempts to tie social network and institutional views of social capital together, essentially tying together Granovetter's concept of network embeddedness with the institutionalist work of theorists such as North (1990) and Ostrom (1990). And Stuart (2003) argues that there are three dimensions of embeddedness: a network dimension; an institutional dimension; and a spatial dimension.

Institutional embeddedness is often more easy to observe than network embeddedness. Networks of relations require detailed surveys of individuals regarding their contacts (though research on internet-based relations are altering that). In contrast, many types of institutional embeddedness can be externally observed because the institution is easily observed. One obvious example is gender - one way to think about the impact of gender on the thoughts and actions of individuals is to think of it as an institution that prescribes certain rules of thought and behavior. We can easily observe the gender of individuals, and so we can easily observe their position within the institution of gender. Obviously, this is a crude first cut at examining an individual's institutional embeddedness, but it nevertheless captures a lot of important data.

and cognitive (ibid., 37). What is missing from these discussions is an attempt to integrate the different types of embeddedness into a coherent analytical framework. 
I will focus on caste membership in rural villages in Andhra Pradesh as the site of embeddeness for the purposes of this. Broad caste categorizations are easily observed, at least by people with some knowledge of the society, by, for example, imputing the caste status of an individual from their name. There are obviously network consequences and underpinnings of caste as an institution, but for the sake of clarity I will treat caste as an institution, and membership in a caste as an institution with important consequences its members think and act, and how they are thought of and acted upon by others.

\section{Institutions, embeddedness, and organizations}

The purpose of this paper is to examine how the creation of a new organization must contend with the institutional embeddedness. It also examines how the creation of new organizations introduces new institutions into the lives of people that it recruits as members and serves. As such, it makes sense to clarify how institutions are different from organizations, and how they affect each other.

Organizations and institutions are different (North 1990, 5). At the heart of organizations is a set of "coordinated and controlled activities" (Meyer and Rowan 1990, 41) conducted by a fairly well-defined group of people. ${ }^{4}$ Institutions are sets of persistent formal and informal rules of practice that are enforced through sanctions and rewards. The rules

\footnotetext{
${ }^{4}$ Open systems theories of organizations highlight the fact that organizations are often shifting coalitions of different sets of people (Scott 1987, 23). Nevertheless, it would be an exaggeration to argue that one cannot find fairly well-defined groups of people engaged in certain agreed-upon activities over a particular period of time that one can call organizations. What open systems theory tells us is that the boundary between who belongs and who does not belong in the organization is often difficult to define and porous.
} 
govern a wide range of practices, from how to greet someone to how a loan underwriter assesses the risk of a loan to a particular loan applicant (Garfinkel, 1967; Stuart 2003, 70104). Many institutions are so ingrained that the practices they prescribe are taken for granted. They are also ingrained in that they not only affect what people do, but how they think (Douglas, 1986). Institutions inform the activities of organizations by prescribing practices and ways of thinking that are considered legitimate, "state of the art," "best practices," required by professional or state regulations, etc.. Thus institutional rules can cut across the boundaries of organizations. For example, the human resources department of a corporation that hires a psychologist is bringing into its organization the formal rules of psychology in the person of the psychologist. This will affect how the organization relates to its employees, because the psychologist will be engaging in activities that are informed by the rules of the psychology profession. ${ }^{5}$ But organizations can also develop their own institutions - a particular way of doing things that is taken for granted within the organization. And, finally, organizations can promulgate and enforce institutional rules, the most obvious example being the role of professional associations in promulgating and enforcing the rules of their institutions.

Neo-institutional theory in sociology posits that institutions evolve slowly, often without conscious design (DiMaggio and Powell 1991, 8). This hypothesis is open to empirical investigation. In the sphere of economic development there are myriad examples of attempts to introduce new institutions into the everyday lives of people with the aim of

\footnotetext{
${ }^{5}$ It also may be the case that the organization decides it wants to take advantage of the analytical tools of psychology in their human resources activities, and, hiring a psychologist is part of that effort.
} 
changing the way they interact with each other and the rest of the world in ways that improve their lives. One strategy for introducing new institutions into an existing social structure, characterized by its own institutions, social relations, and spatial configuration, is to introduce them through the medium of an organization; in particular, an organization that is to be run by the people whose lives are to be changed. ${ }^{6}$

Such an organization must confront the fact that its new practices will bump up against existing practices. The organization will require the attention and time of people with already prescribed roles in the existing social structure. Such requirements may run into the fact that other practices already take up all the time of those who might run the organization, or they may run into the fact that they require potential "managers" to engage in socially prohibited activities. A person can try to manage any contradictions that exist between their new role in the organization and their existing role by trying to decouple their activities, and to limit public (sanctioning) knowledge of their prohibited actions. But their ability to do so is constrained by the other dimensions of their embeddedness. A person engaged in contradictory practices that involve others, who, in turn, know each other will result in their being "found out." Or a person whose contradictory practices are confined to a particular place may find it difficult to decouple the contradictions, even in their own minds.

\footnotetext{
${ }^{6}$ There are other ways to change institutions. For example, through education or political mobilization. Ostrom (1993) contains myriad examples of the establishment of organizations to promulgate and enforce new institutions. Cooke and Kothari (2001) also offer a critical perspective on attempts to establish new institutions through organizations that are managed by the people affected themselves.
} 
On the other hand, a new organization may also be able to take advantage of existing institutions, and the embeddedness of people involved in the founding of the organization in those institutions. For example, an existing social hierarchy in which certain people are accorded trust by the mere fact of their status may work to the benefit of an organization that is promoting change and whose leader is a high-status person. This is the paradox of embeddedness: it can both facilitate and obstruct the introduction of new institutions; furthermore, it is unclear what is achieved if there is no institutional resistance to new practices - if the introduction of the new organization is too easy it is likely that it will not have been transformative.

In the case I discuss in this paper, an organization, the Cooperative Development Foundation $(\mathrm{CDF})$, introduced new institutions into an existing set of village social structures in two impoverished, rural districts. These institutions are a set of formal rules established through the medium of an organization, a cooperative. The rules determine membership in the organization, how it collects and organizes information (accounting practices), how it governs itself, and, hence, how those with authority should make decisions about the collection and disbursement of resources (money). As I will describe in more detail below, each village has its own autonomous cooperative, but all the cooperatives follow the same rules and operate under the auspices of a federation of cooperatives, with the technical assistance and guidance of the CDF. Furthermore, the practices that the $\mathrm{CDF}$ promulgates are in turn informed by the guiding principles of the International Cooperative Alliance. 


\section{Data Collection and Research Site}

The primary data I present in this paper are from computerized accounts of 27

cooperatives, the census of India, and interviews and written reports gathered over an extended period of time between 2001 and 2006. The computerized accounts contain financial and member demographic data for the years 2004 and 2005. The 27 cooperatives are members of three Associations of Women's Thrift Cooperatives (AWTCs) operating in the Karimnagar district of Andhra Pradesh. They include some of the oldest and most well-established cooperatives in the confederation supported by the CDF, but they also include fairly new cooperatives. They have over 17,000 members and as of the end of 2005 they had over Rs. 54 million in loans outstanding (over \$1 million). Table 1 presents data on all the cooperatives working with the CDF and the 27 WTCs in this study.

\section{TABLE 1 ABOUT HERE}

The computerized and census data provide the basis for the quantitative analysis that follows. The interviews and written reports provide data on the formal and informal functioning of the WTCs, and thus provide data on the context in which the quantitative data were produced and the causal mechanics driving them. The interviews were with the staff of the Cooperative Development Foundation (CDF) and members and leaders of the WTCs. One member of the research team, who is fluent in Telegu, the local language (spoken by about 80 million people), conducted the interviews with members of the WTCs in July and August 2001. These interviews were semi-structured and lasted about 
60 minutes. The sample of members is heavily biased towards the leadership of the WTCs - members of the boards of directors of the thrifts, their presidents, and the presidents of the associations of WTCs. Furthermore, the WTCs of which they are members have been in existence for longer than average, and not all the interviews were with members of the cooperatives with computerized data. The written reports are from the $\mathrm{CDF}$, and are largely annual reports sho wing the overall financial condition and organizational reach of the cooperatives.

The CDF supports cooperatives in the Karimnagar and Warangal districts of Andhra Pradesh, which are about $150 \mathrm{~km}$ north and northeast of Hyderabad. They have a population of about 3.5 million and 3.2 million respectively, and population densities of 294 and 252 people per square kilometer respectively (Census of India 2001). It is an area that is troubled both politically and economically. Politically, Naxalite (Maoist) guerillas operate in these districts. Economically the districts are some of the poorest in the state, and their literacy rates lag slightly behind the state average of $71 \%$ for men and $51 \%$ for women (ibid.).

\section{Formal structure and functions of the cooperatives}

Cooperatives in many parts of India have an extremely poor reputation. They very often are cooperatives in name only and are vehicles of political influence and corruption (Baviskar and Attwood 1995). The Cooperative Development Foundation (CDF) grew out of a direct response to the mismanagement of Primary Agricultural Cooperatives in Andhra Pradesh in the 1970s. Initially the group who went on to found the CDF were interested in reviving flagging Primary Agricultural Cooperatives (PACs) in the district 
of Rajendranagar, near Hyderabad. In the 1970s they promoted the consolidation and reorganization of PACs in their district and in Karimnagar. During the 1980s the CDF worked to support cooperatives in the state, and lobbied the government to reform the state's cooperative societies act, with limited success. In 1993 CDF changed course: instead of lobbying for a change in the existing cooperative law, it lobbied for a new, parallel law under which cooperatives could opt to be regulated. The change was due to the realization on the part of the $\mathrm{CDF}$ that the interests vested in the existing cooperative structure were too great and too politically powerful to allow for its reform. A parallel law was an attempt to mitigate the opposition from these interests. In 1995 the CDF succeeded in its goal when the state legislature passed the Mutually Aided Cooperative Societies Act (MACS Act) (Cooperative Development Foundation, 2001b).

While it was campaigning to promote PACs and legal reform, CDF embarked on its efforts to form the women's thrift cooperatives. Initially the CDF tried to promote the involvement of women in existing cooperatives, but found male members of those cooperatives resistant to the idea. So they decided to promote new, women-only cooperatives. After some false starts working through another organization in the late 1980s, the CDF began directly promoting the formation of women's thrift cooperatives itself. It focused on the districts of Karimnagar and Warangal, and the first WTC was founded in 1990 (Reddy, 2001).

The cooperatives are self-managing, and self-financing, organizations. The members of each cooperative elect a board of directors at an Annual General Body Meeting, which in 
turn elects a president from their number. The board members sit for three years in staggered terms, while the presidents sit for one year. Both can be reelected indefinitely. Each cooperative is a member of an association of cooperatives (AWTCs). The cooperatives' presidents serve as directors of their respective AWTCs and elect the president of the association at an Annual General Body Meeting. The board of directors of each cooperative decides on loan applications from members, and, with the help of a paid accountant trained by CDF but from the membership of the cooperative itself, manages the day-to-day activities of the organization.

Despite the emphasis on self- management and self-financing, CDF is heavily involved in the cooperatives in the first two years of their lives. They train the president and the accountant to use a book-keeping system. They audit the books of the association every month, and audit every new cooperative in that association every three months. Once the cooperatives have matured, the CDF continues to audit the association monthly, but lets the association auditor audit the cooperatives, except for a test audit that CDF conducts once a year on each cooperative. At their most mature, cooperatives are no longer audited by CDF, but CDF continues to audit the association monthly. Thus there is a rigorous process of training and development through which WTCs go under the guidance of the CDF. As a result, the WTCs have in place formal governance and management systems based on a model developed by the CDF, which is in turn informed by the principles of the International Cooperative Alliance. 
Beyond the initial training and development phase of the relationship between the CDF and the WTCs, there is an on- going process of interaction. First, the CDF continues to provide training to the accountants, presidents, and cooperative directors. Second, the CDF receives monthly reports on the activities of the cooperatives through their associations, in a format similar to the one that the presidents of the cooperatives themselves receive at the monthly association meetings. In this way, the CDF is able to monitor the general health of the cooperatives. Finally, the CDF has created a formal structure through which it learns from the WTCs. CDF staff and the leadership of the AWTCs meet monthly to discuss the functioning and future of the cooperatives. These meetings run on a regular schedule, beginning in April of each year and ending in October. At that time, the leaders of the associations jointly decide on any new policies for the cooperatives to come into effect the following January. In addition, as CDF has grown it has hired women who were once members of the cooperatives.

The cooperatives have a total membership of about 70,000 women. Membership is conferred on any woman within the WTC's service area who pays the initial membership fee and the first month's thrift amount. To be a member in good standing, with borrowing privileges, a woman has to be current on her monthly thrift payment. In the early years of the WTCs members saved Rs.10 per month, but it is now common to find WTCs requiring Rs. 20 or Rs. 30 per month (about 40 to 60 cents per month). Some require as much as Rs. 80 per month.

FIGURE 1 ABOUT HERE 
Since their inception the WTCs have allowed members to borrow from the cooperative in amounts that are tied to the amounts they have in their various deposit accounts. Initially the WTCs only offered one type of deposit account, the thrift account, and the rule was that a member could borrow up to three times the amount in her thrift, so long as she had two co-signers and the approval of the board of directors.

In 1999 the cooperatives adopted a number of changes, under the guidance of the CDF. They created three new savings products: savings accounts, recurring deposits, and fixed deposits. They also introduced a new life insurance scheme, the Debt Relief Assurance Scheme (DRAS). The scheme, now called Abhaya Nidhi, requires a premium payment of between Rs.500 and Rs.1,000, depending on the age of the member, in return for which the survivors of the member will get Rs.10,000 when she dies, after clearing the outstanding debt, if any, in the account of the deceased member. The premium can be paid in a lump sum or in installments.

They also changed the way they made loans. They asked their members to form Joint Liability Groups (JLGs) of about five women to act as mutual guarantors of loans made to members of the group. For a group member to be eligible for a loan, all members of the group must be in good standing on their thrift and loan payments. Furthermore, all members of the group must sign the loan application of any single member, and, as a result, they are formally guarantors of the loan. Though the members did not like this new system of joint liability, they had a good reason to join a group: members are only eligible for a loan up to three times their thrift amount if they are a member of a JLG; 
otherwise they are only eligible for a loan up to $85 \%$ of their thrift amount (initially it was only $75 \%$ ). In addition to the introduction of the JLGs the cooperatives began to advance loans against the amount in the new savings accounts they offered, though the limit was, initially, only $75 \%$ of the amount in the account. Now it is $85 \%$.

Since these major changes, the cooperatives have made some further, minor, adjustments to their product offerings. They now allow members to borrow up to three times the premium they have deposited in their insurance account. At the end of 2004 they created a separate "bonus" account, into which the cooperative deposits the member's annual dividend based on the amount they have in their thrift account. Members are now eligible to borrow up to three times the amount in this account. Finally, some cooperatives have introduced a new gold loan for borrowers who own gold and wish to borrow against it.

Despite these developments the basic structure of the relationship between members and the cooperatives has remained the same. As I will demonstrate in more detail below, almost all the borrowing from the cooperatives is done against the thrift and bonus accounts. As a result, how much members are willing and able to borrow is tied very closely to how much they have accumulated in these accounts, and, as a result, how long they have been a member.

The cooperatives charge varying rates on their loans depending on the size of the organization. New cooperatives charge $2 \%$ per month, while more established 
cooperatives, with a larger deposit base, charge $1.5 \%$ per month. ${ }^{7}$ Up until 2003, all cooperatives paid $1 \%$ per month on the thrift amount in interest to their members, and less on the other, fixed deposit accounts. Now, as was noted above, the interest on the thrift account is paid out as a dividend at the end of the year, based on the surplus earned by the cooperative and the amount each member has in her thrift account. This change occurred because the $1 \%$ interest per month on the thrift was creating a financial squeeze for many cooperatives, because they were not earning enough on their loans to cover their costs. This was not because the cooperatives are a high-cost operation, but because their fund utilization rate was, and is, around $80 \%$ on average - they only lend out about $80 \%$ of the funds they have on hand, which means that they are only earning interest on $80 \%$ of their funds. By changing the way in which the thrifts pay interest on the thrift amount, the cooperatives have been able to gain some relief from the financial squeeze they were facing, because they only paid out what they could afford.

The cooperatives are rule-driven organizations that have adapted over time as they have learned what has worked and what has not. Most of these changes have been in the products the cooperatives offer their clients; their formal governance structure has remained largely the same. Despite the changes the cooperatives' financial relationship with their members is largely dictated by the amount they have accumulated in their thrift

\footnotetext{
${ }^{7}$ The interest rate a WTC charges varies with its deposit base: WTCs with a deposit base less than Rs.500,000 charge 2\%; WTCs with a deposit base of between Rs.500,000 to Rs.1 million charge 1.75\%; and WTCs with a deposit base of over Rs.1 million charge $1.5 \%$.
} 
and bonus accounts, a direct product of the length of time a member has been in the cooperative, and the "three times" rule. ${ }^{8}$

\section{Embeddedness, institutions, and the cooperatives}

The formal structure and functions of the cooperatives include separate organizations for women and men, democratic governance, and product offerings designed to give all members access to savings and credit services, so long as they can make the monthly thrift deposit. They do so in the context of a rural social structure in which gender and caste play a powerful role in determining how people participate in village social, economic, and political life. How have the formal structure and functions of the cooperatives fared in this context? The next section addresses caste embeddedness and the following section addresses gender embeddedness, paying particular attention to its caste context.

\section{Caste Embeddedness}

The Indian government has established a caste categorization system through which it implements its affirmative action programs to counter the debilitating effects of caste on those in its lower ranks. The categorization system consists of three explicit categories, and one residual one. These are: the Scheduled Tribes (STs) - members of India's

\footnotetext{
${ }^{8}$ The "three times" rule does not apply to thrift accounts with a balance less than Rs.1,500 (just over \$30). A member with Rs.100 to Rs.500 in their thrift account can borrow six times the amount or Rs.2,500, whichever is less; a member with Rs.500 to Rs.1000 can borrow five times the amount or Rs.4,000, whichever is less; and for those with Rs.1,000 to Rs.1,500 the limit is four times or Rs.4,500, whichever is less. (Cooperative Development Foundation 2005, 9)
} 
indigenous population; the Scheduled Castes (SCs), also known as the Untouchables or Dalits; the Backward Castes (BCs), who are disadvantaged members of the lowest ranks of the caste structure; and the residual group, the Other Castes (OCs), who are members of the more advantaged castes and also non-Hindus (mainly Muslims in the case of Andhra Pradesh). These categorizations are commonly understood within Indian society and are the categories used to understand the role of caste embeddedness.

The persistence of the impact of caste on the activities of people in India is the subject of debate, especially in the light of government efforts to extend its affirmative action policies to the BCs. Space does not allow an extensive discussion of caste as a sociostructural phenomenon in India, nor is such a discussion necessarily relevant given extensive regional variations in the social structure, and variations between urban and rural areas. Nevertheless, there is a straightforward measure of the role that caste plays in the villages in this study that provides a good indication of the role caste still plays in these villages. The accounts data identify the Joint Liability Groups (JLGs) in each WTC and the caste identity of each member of the group. As was noted above, members of the same JLG bear a considerable amount of responsibility towards each other, and it is highly likely that they know each other well. The women form the groups voluntarily, with no direction from the CDF as to who should be in the group. As a result, the caste composition of the groups in a WTC can give us a good indication of the role caste plays in the economic decisions of the women members of the cooperatives. If caste embeddedness is weak then we would expect the JLGs to have a diverse membership: each group would have members from a variety of castes, and the number of diverse 
groups would roughly equal to the number one would see if people were assigned randomly to groups. If caste embeddedness is strong then we would expect to find a large number of homogenous groups - people of the same caste grouped together, in numbers higher than one would expect through a random assignment process.

The data clearly show that the groups in each WTC are far more homogenous than one would expect if group assignment were random. The average percentage of groups that are diverse produced by 1,000 random simulations in each cooperative varies from $54 \%$ in Prataparudra to $98 \%$ in Katkur. In contrast, the actual percentage of groups that are diverse only varies from eight percent (8\%) in Rangayapalli to $65 \%$ in Katkur (Table 2a). In no village, did the number of diverse groups generated in 1,000 simulations fall as low as the actual number of diverse groups in each of the cooperatives. As a result, we can be highly confident that the large number of groups that are homogeneous with respect to caste is not random. This suggests that caste embeddedness remains strong in the cooperatives in this study.

TABLES $2 \mathrm{a}$ and $\mathrm{b}$ ABOUT HERE

The data also suggest that the lack of caste diversity is due to the lack of inclusion of Scheduled Caste members in groups with Backward and Other Caste members. The number of diverse groups with SC membership in groups with $\mathrm{BC}$ or OC members is far less than one would expect through random assignment. Furthermore, the number of groups where there are members from three different castes (or more) are severely under- 
represented (Table 2b). In the case of STs, the data are less decisive, but this is likely due to the small number of STs in many of the cooperatives. In sum, the data suggest that an important caste fault line is between SCs, on the one hand, and BCs and OCs, on the other.

This last finding is an important element in understanding how caste embeddedness is likely to play out in the face of new institutions. The caste structure is, by its very nature, hierarchical. The cooperatives are, on the one hand, open and democratic, but, on the other hand, offer advantages to their members and have a hierarchical governance structure (they have a board of directors and president). In such a context, caste embeddedness can play two different roles. One is a hierarchical one: membership favors the advantaged castes, they will dominate the leadership positions, and they will have greater access to the services the cooperatives offer. The other is a representative one: each caste group will ensure, through institutional and non-institutional means, that its members get their fair share. The next two sections address these hypotheses directly.

\section{Membership and Leadership}

The WTCs are intended to serve all the eligible women residents of the villages in which

they are located. There are no barriers to membership except the monthly thrift payment. One would expect the membership of the WTCs to reflect the population of the villages (Table 3a). In 15 of the 27 cooperatives SCs and STs are underrepresented when compared to the composition of the villages they serve. In six they are overrepresented, and six their representation in the cooperatives is no different from their representation in the villages the serve (Table $3 b$ ). Census data are not available on the size of the 
Backward Caste and Other Caste populations, so it is not possible to measure the extent to which one or the other of these castes is over- or underrepresented in the membership.

\section{TABLE 3a AND b ABOUT HERE}

The cooperatives are democratic organizations holding elections for their board of directors and president every year, though on a three- year rolling basis for each director. If caste embeddedness plays a hierarchical role in the selection of the leadership then one would expect an overrepresentation of $\mathrm{OC}$ and $\mathrm{BC}$ members in the leadership of the WTCs. If caste plays a representative role, or no role at all, then one would expect the leadership to reflect the composition of the membership.

Each cooperative has 12 board members. The number of board members in each cooperative is too small to conduct a village-by-village analysis, so the analysis of potential bias at the board level must be conducted across all 27 cooperatives as a whole. ${ }^{9}$ The membership of the WTCs is $17 \%$ SC and 3\% ST, while the boards of directors are $15 \% \mathrm{SC}$ and $1 \% \mathrm{ST}$. This suggests that the SCs are well represented on the boards of directors, while the STs are not so well represented. At the presidential level only two of the 27 presidents are SCs and there is one ST president. The position of the SCs and STs

\footnotetext{
${ }^{9}$ Unlike in the case of membership, which can vary in size, the number of directors is constant for all cooperatives, except for a few boards with unfilled seats. As a result, there is unlikely to be any bias introduced into the aggregate analysis of the cooperatives as a whole due to individual cooperative idiosyncracies.
}

DRAFT, August 2006 
has improved over time. We have membership, board of director, and presidential data on 24 of the 27 WTCs from 2001. A comparison of these 2001 data with those from the end of 2005 show they have gained eight board seats while their share of the membership has only increased slightly. Furthermore, two of the three presidencies the SCs and STs held at the end of 2005 were not held by them in 2001 (Table 4).

\section{TABLE 4 ABOUT HERE}

The membership data identify $\mathrm{BC}$ and $\mathrm{OC}$ members. The membership is $65 \% \mathrm{BC}$, and the boards are 59\% BC, but only eight (8) of the 27 presidents are from the BC. In contrast, Other Castes are 16\% of the membership, 22\% of the boards, and 16 out of 27 of the presidents. In other words, the $\mathrm{BC}$ members are under-represented at the board level, and even more so at the level of president, while OCs are over-represented at both these levels. Comparing the situation with that in 2001, there has been very little change in the share of $\mathrm{BC}$ board seats and in the share of $\mathrm{BC}$ membership, while the $\mathrm{OC}$ membership share has fallen slightly and the OC share of board seats has fallen more significantly.

The interpretation of these data raise questions about the role of caste in the workings of the cooperatives. We do not have good ethnographic data to explain the differential representation of the different castes in the membership of the cooperatives or on their boards. One possible explanation of the board representation data is that the SCs have acted in solidarity to ensure their representation on the boards of the cooperatives, while 
BCs have been less conscious about favoring their own caste and have been willing to support OC board members. This is consistent with the group data showing a great deal more caste mixing of BCs and OCs than of SCs or STs and either of the two more advantaged castes.

At the presidential level, the interviews with the presidents of the cooperatives and with the CDF outreach staff suggest that the presidents gained their positions because of their caste status. Though the presidents all played down the role their caste status played in their accession to the leadership of their WTC, it is clear that this had a direct role. For example, two women described how the outreach staff of the CDF held the first meeting regarding the formation of a WTC in their village at their respective houses, because of their families' leadership status in the village. Another described how her husband's connections to the CDF through membership in ano ther cooperative resulted in her becoming the president of the WTC in her village (Sarojini). And a fourth gave multiple reasons why she was elected president: she was "already recognized as a leader in the village," came from a "respected family," and knew all the original members of the cooperative (Marapati). These descriptions of the strategy CDF used to gain access to and the confidence of the women in the villages where they promoted the cooperatives are consistent with data from interviews with the CDF outreach staff.

In some ways, women from the Reddy caste are not in a good position to be presidents of the WTCs because of traditional restrictions on their movement outside the household. Nevertheless many of the women interviewed described a variety of ways in which they 
managed to overcome the gender constraint they faced, something I will discuss further below. Furthermore, the women argued that they were better suited to be president either because of their education or because of the financial standing of their family. One common theme in the interviews with the presidents was that they carried an enormous amount of responsibility for the management of their cooperatives. If they made any mistakes, they felt they were liable. And this was sometimes used to rationalize the need for a higher caste person to be president: they could afford the responsibility and were most capable of handling it. There is evidence that this high level of responsibility is the product of the expectations of the members. The interviews gave the impression that the women think of the WTC as another type of chit fund - a traditional revolving loan fund with which the women have a lot experience. One feature of a chit fund is that it is run by an individual with a good reputation in the village. In exchange for helping to organize the fund the leader either receives a fee or is given the first loan from the fund, interest free. The presidents of the WTCs often play a similar leadership role, though their direct mo netary reward is less. ${ }^{10}$ In other words, though caste bias is likely a factor in promoting the upper caste women into the role of president, how they come to be president is multi-faceted: from the initial contact the CDF outreach workers make; to their educational and financial advantages; to the construction of the role of president as

\footnotetext{
${ }^{10}$ As with chit funds, WTCs are vulnerable to the reliance their members place on their leaders. There have been instances where a president has taken out loans in the name of other members and then failed to repay them. In one instance the members pursued the corrupt president and seized her land, on which they subsequently built offices for the WTC.
}

DRAFT, August 2006 
being one of high responsibility, something that biases the selection process towards women whose household's finances can withstand losses that might come from mistakes.

\section{Access to services}

Though there is some under-representation of SC/ST groups in the cooperatives, they are organizations with a diverse membership. Such diversity means little if only a select group is taking advantage of the services the cooperatives offer. Almost all the money the members have accumulated in the cooperatives is in thrift, bonus, or Abhya Nidhi accounts. As explained above, the first two of these accounts operate according to established rules regarding membership. In essence, they are not discretionary, and if an individual is not using these accounts then their membership is in jeopardy. The life insurance account is discretionary - a woman can choose to buy insurance or not, so we can test to see if members of different castes are using this product equally. In addition, loan use is discretionary, though it is largely tied to the non-discretionary funds accumulated in the thrift and bonus accounts - members can choose to take out a loan, but they are limited to an amount that is three times the amount in their thrift and bonus accounts. So a test of whether all members are taking advantage of the loans that their cooperatives offer is to measure the extent to which they are all borrowing equally against the funds they have accumulated in their accounts.

The distribution of the life insurance product across caste in all but three of the 25 cooperatives reflects the caste distribution of the membership of each cooperative. ${ }^{11}$

\footnotetext{
${ }^{11}$ I used a chi-square test to test for representativeness with a p-value of 0.05 as the cut-off for significance.
} 
The accounts data show the number and amount of loans outstanding at the end of 2005 . These data are a good measure of loan use, in that they provide a snapshot of the demands that members are making on the cooperatives for loans. Of the 10,750 loans outstanding at the end of 2005, all but two were loans borrowed against the thrift, bonus, life insurance, or savings accounts of the members. This is indicative of the fact that the cooperatives have been fairly conservative in their development of new loan products, and only a few cooperatives offer products that go beyond these basic offerings. The analysis which follows will focus on the basic loan products that all the cooperatives offer.

Loan use in all but six of the 27 cooperatives reflects the caste distribution of the membership. But a comparison of the means of the amounts borrowed by each caste group in each cooperative shows that in 20 of the 27 cooperatives there is a clear, statistically significant, difference in how much the groups are borrowing. And in almost all of these cases the average amount borrowed by each group follows the caste hierarchy, with OCs borrowing more than BCs, and BCs borrowing more than SCs and STs. ${ }^{12}$

But, as noted above, borrowing from the cooperatives is tied to the amount a member has in her accounts. A comparison of the outstanding loan balance to the savings balance across the three basic accounts and the other savings products shows that in all but five of

\footnotetext{
${ }^{12}$ I used the KrukatWallis test to test whether the sample means are significantly different, using a p-value of 0.05 as a cut-off for significance. Standard ANOVA comparison of means yielded the same results.
} 
the cooperatives there is little caste influence on the distribution of loan amounts. In other words, in all but five of the cooperatives the mean of the loan balance to savings balance ratio of each caste group is not significantly different from any of the others. As a result, the reason why the lower caste groups have a lower outstanding loan balance in most of the cooperatives is because they have a lower savings balance. And the reason they have a lower savings balance is because, on average, they have been members for fewer days (Table 5).

Finally, it should be noted that 12 of the 27 cooperatives have at least one loan out to a member against the three basic accounts that exceeds the $3: 1$ rule. Of these 12 , six broke the rule for at least one member from each caste group and six broke the rule for some castes and not others. Overall the number of loans that exceed the 3:1 rule is less than $10 \%$ in all but two of the cooperatives.

In sum, these data suggest that the cooperatives' rules regarding the provision of financial services are enjoying a fair degree of compliance. The close link between length of membership, savings accumulation, and outstanding loan balance are in line with what one might expect given the rules of the cooperative. Though a key component of the way the cooperatives originate loans, Joint Liability Groups, shows the unequivocal influence of caste on member's economic behavior, the outcome, in terms of access to loans shows little caste impact in almost all the cooperatives. It may be the case that the homogeneity of the JLGs contribute to this equitable access, because their ability to gain access to 
loans is bolstered by caste-based group solidarity, but this requires further analysis, beyond the scope of this paper.

\section{Gender Embeddedness}

With respect to gender, it is clear that the cooperatives have done well. The very existence of 256 women's thrift cooperatives is evidence that the CDF and the women have succeeded in confronting gender embeddedness -- despite the resistance from men. In particular, it was necessary for the women leaders to confront the resistance within their household to their efforts to build the cooperatives - a task that fell heavily on their shoulders. For example, one president described the challenges she faced:

I never went out on my own any time in the past. My mother-in- law managed everything from the beginning. I lived a highly secluded and confined life. We had to move in purdha (veil) when we went out. I was very afraid of my mother-in-law, though she used to respect me. She controlled every wakeful hour of mine and made us do all the household work. She was a big mouth and an authority figure in the community...

As my responsibilities increased I had no time for housework. My husband used to get quite irritated. When he shouted in anger, I used to keep silent. My children used to miss me at home and feel upset. My daughter used to help me till she got married in 1998. Once we found an accountant to take care of the accounts I felt a great relief. Managing the accounts gave a lot of headache. I used to fear that some thing may go 
wrong and used to get quite exercised. Seeing that my husband used to get very upset and sought me to give up the whole thing. But I stuck on. And am happy I did so...

Especially since 2000 my husband has came to accept my WTC and AWTC (association of cooperatives) preoccupations gradually. Though he shouts sometimes, the next day he encourages me to go to office and take care of the AWTC business... My son in law, however, continues to discourage... Once I come to the WTC office I forget the house duties completely. Here people respect me and recognize me. (Kasala)

Based on our interviews with the women leaders, this story is not uncommon. It speaks of a direct conflict between an attempt at institutional change - women running their own financial institution, and the existing social structure. This conflict played out in the households of the women leaders and resulted in a profound change in how they are viewed within the household and within their community.

\section{Discussion and conclusion - institutional change and embeddedness}

In important ways the new rules for managing an important part of the local economy introduced by the CDF through the promotion of cooperatives, and promulgated by the women members of those cooperatives and their leaders, are working well. In particular, the $\mathrm{CDF}$ and the women have established women-run organizations, with boards that are 
representative of their membership, and access to financial services consistent with the formal rules of the cooperatives.

These successful changes engaged embeddedness in a variety of ways. In the case of establishing women-run cooperatives the CDF and the women directly challenged existing gender social structures, and, after a struggle, prevailed. In the case of the board representation, the cooperatives have evolved from a situation of under-representation of the SCs in 2001 to more equal representation by the end of 2005. Obviously such an evolution could not have taken place without the formal democratic mechanisms the cooperatives have in place. But it may also be the case that caste embeddedness has played a part in that evolution through conscious caste voting on the part of the SCs -that remains an open question that requires further research. In the same way, equal access to financial services, especially loans, is clearly driven by the cooperatives' rules regarding loan size limits. But it may also be the case that embeddedness has abetted this through the homogenous JLGs that allow fellow caste members to support each other's efforts to borrow from the cooperatives.

It is also clear that the cooperatives have engaged embeddedness, and the latter has prevailed. As was noted above, the groups the women formed to enable the cooperatives to better manage their credit risks are highly embedded in the existing caste structure. In fact, the group homogeneity provides unequivocal evidence of the role that caste still plays in the villages in this study. The evidence also suggests that the CDF's strategy of gaining access to villages through the existing social hierarchy has had lasting effects on 
caste background of the presidents of the cooperatives. Furthermore, though the cooperatives are open to all women villagers, the data suggest that the lowest castes are still under-represented. One possible explanation for this is that the SCs and STs were slower to join the cooperatives, because, as the most vulnerable members of society, they had the most to lose if the organizations did not survive. Such an explanation finds support in the data showing that SC and ST members have, on average, been members for fewer days than the other members. Another possibility is that the monthly thrift rule excludes the poorest, who are most likely to be lower caste, from joining the cooperatives because they can not comply with the rule.

As in the case of the successful changes, the instances where embeddedness seems to have prevailed are a product of varied engagement between the new institutional rules and embeddedness. In the case of the presidential leadership, there seems to have been a deliberate strategic choice to work with the existing hierarchy. In the case of the JLGs it is likely that indifference was and is the predominant attitude - what is important is that the women form groups rather than what types of groups they form. In the case of the membership composition of the cooperatives it is unclear what attitude prevailed and prevails - more research is needed on this.

The evidence in this paper suggests that as attempts at institutional change engage the existing social structure they can result in conflict, mutual reinforcement, or indifference. The evidence also suggests that the engagement can evolve, especially if the institutional rules make space for such an evolution. The evidence has also raised a number of 
questions that require further research. Most importantly more detailed ethnographic work will allow us to understand the variations in the ways the engagement between the cooperatives and the caste structure have played out in the different villages in this study. There also needs to be further work on the role that caste-consciousness plays in affirmatively promoting the position of one group or another in the running of the cooperatives. These research questions point to a broader practical point -- context matters. We can draw broad lessons from the type of data presented here that can inform efforts to promote institutional change. But the results of our efforts in practice will be highly contingent on the context. 


\section{Bibliography}

Anderson, C. L., L. Locker, et al. (2002). "Microcredit, social capital, and common pool resources." World Development 30(1): 95-105.

Bourdieu, P. (1986). The Forms of Capital. Handbook of Theory and Research for the Sociology of Education. J. Richardson. Westport, Conn., Greenwood.

Carruthers, B. and S. Babb (2000). Economy and Society: Markets, Meanings, and Social Structure. Thousand Oaks, CA, Pine Forge Press.

Casson, M. and M. D. Giusta (2004). "The Costly Business of Trust." Development Policy Review 22(3): 321-342.

Census of India (2001). Provisional Population Totals: Series-29, Andhra Pradesh. Hyderabad, Census of India.

Cooperative Development Foundation (2001a). Performance of Women's Thrift Cooperatives (WTCs) at a Glance: 1990-00. Hyderabad, Andhra Pradesh.

Cooperative Development Foundation (2001b). 25 Years of Learning, 1975-2000. Hyderabad, Andhra Pradesh.

Cooperative Development Foundation (2005). Swa-kru-shi Thrift Cooperatives around Warangal City in Andhra Pradesh, Performance Report: 2004, Warangal, Andhra Pradesh.

DiMaggio, P. and W. W. Powell (1991). Introduction. The New Institutionalism in Organizational Analysis. P. DiMaggio and W. Powell. Chicago, University of Chicago Press.

Douglas, M. (1986). How Institutions Think. Syracuse, N.Y., Syracuse University Press. 
Fligstein, N. (2001). The Architecture of Markets: An Economic Sociology of TwentyFirst-Century Capitalist Societies. Princeton, NJ, Princeton University Press.

Fukuyama, F. (1995). "Social Capital and the Global Economy." Foreign Affairs 74(5): 89-103.

Garfinkel, H. ([1967] 1984). Studies in Ethnomethodology. Oxford, U.K., Polity Press.

Gomez, R. and E. Santor (2001). "Membership has its privileges: the effect of social capital and neighbourhood characteristics on the earnings of microfinance borrowers." Canadian Journal of Economics-Revue Canadienne D Economique 34(4): 943-966.

Granovetter, M. (1985). "Economic action and social structure: The problem of embeddedness." American Journal of Sociology 91(3): 481-510.

Jepperson, R. (1991). Institutions, institutional effects, and institutionalism. The New Institutionalism in Organizational Analysis. Chicago, University of Chicago Press.

Knack, S. and P. Keefer (1997). "Does Social Capital Have an Economic Payoff? A Cross-Country Investigation." Quarterly Journal of Economics 112(4): 1251-1288.

Lefebvre, H. (1991). The Production of Space. Oxford, UK, Basil Blackwell.

Mayoux, L. (2001). "Tackling the Down Side: Social Capital, Women's Empowerment and Micro-Finance in Cameroon." Development and Change 32: 435-464.

Meyer, J. and B. Rowan (1991). Institutionalized Organizations: Formal Structure as Myth and Ceremony. The New Institutionalism in Organizational Analysis. P. DiMaggio and W. Powell. Chicago, University of Chicago Press.

North, D. C. (1990). Institutions, institutional change and economic performance. Cambridge ; New York, Cambridge University Press. 
Oanda.com (2004). FXHistory: historical currency exchange rates, Oanda.com. 2004.

O'Connell, M. (2003). "Anti 'Social Capital:' Civic Values versus Economic Equality in the EU." European Sociological Review 19(3): 241-248\.

Ostrom, E. (1990). Governing the commons : the evolution of institutions for collective action. Cambridge [England] ; New York, Cambridge University Press.

Ostrom, E. and T. K. Ahn (2003). Foundations of social capital. Cheltenham, UK ; Northhampton, MA, Edward Elgar Pub.

Padget, J. (2001). Organizational Genesis, Identity, and Control: The Transformation of Banking in Renaissance Florence. Networks and Markets. J. Rauch and A. Casella. New York, Russell Sage Foundation.

Portes, A. and P. Landolt (1996). "Unsolved Mysteries: The Tocqueville Files II. The Downside of Social Capital." The American Prospect 7(26).

Putnam, R. (1993). Making Democracy Work: Civic Traditions in Modern Italy. Princeton, NJ, Princeton University Press.

Putnam, R. (1993). "The Prosperous Community: Social Capital and Public Life." The American Prospect 4(13).

Quinones, B. R. and H. D. Seibel (2000). "Social capital in microfinance: Case studies in the Philippines." Policy Sciences 33(3-4): 421-433.

Rankin, K. N. (2002). "Social capital, microfinance, and the politics of development." Feminist Economics 8(1): 1-24.

Reddy, R. (2001). Personal Communication. 
Schmid, A. A. (2003). "Discussion: Social capital as an important lever in economic development policy and private strategy." American Journal of Agricultural Economics 85(3): 716-719.

Stuart, G. (2003). Discriminating Risk: The U.S. Mortgage Lending in the Twentieth Century. Ithaca, NY, Cornell University Press.

Swedberg, R. (2004). Economic Sociology. Princeton, NJ, Princeton University Press. The World Bank Group (2004). PovertyNet: Social Capital Home, The World Bank Group. 2004.

Torsvik, G. (2000). "Social capital and economic development - A plea for the mechanisms." Rationality and Society 12(4): 451-476.

Trigilia, C. (2002). Economic Sociology. Oxford, Blackwell Publishing.

Uzzi, B. (1997) "Social Structure and Interfirm Networks: The Paradox of Embeddedness.” Administrative Science Quarterly, 42(1) 35-67

Woolcock, M. (1998). "Social capital and economic development: Toward a theoretical synthesis and policy framework." Theory and Society 27(2): 151-208.

Woolcock, M. and D. Narayan (2000). "Social capital: Implications for development theory, research, and policy." World Bank Research Observer 15(2): 225-249. 


\section{Figure 1 \\ Swa-kru-shi \\ Cooperative Thrift and Credit Network}

1. Structure and membership :

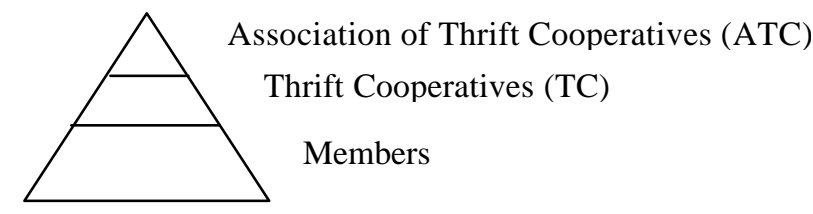

2. Thrift Cooperative's Size

300 - 1000 Members

3. Joint Liability Group (JLG) :

5 Members, voluntarily organized

4. Director's Term

3 Years

5. President

Elected by Board Members from among themselves

6. Term

1 Year

7. Staff

Bookkeeper

8. Saving Products

Compulsory Thrift

Fixed Deposit

Recurring Deposit

Savings Deposit

9. Loan Products

Three times Compulsory Thrift, Bonus, and/or Life Insurance Premium Deposit $85 \%$ of Thrift (non group members) $85 \%$ of Fixed Deposit

85\% of Recurring Deposit

$85 \%$ of Savings Account

10. Insurance Products

Life Insurance

Group Insurance

Accident Insurance

11. Allocation of Surplus

Net surplus allocated pro rata

12. Interest on Loan on Compulsory Thrift, Bonus, \& $18 \%$ to $24 \%$ (depending on TC's funds) Life Insurance Deposit

13. Meetings

General Body: annual, ordinary, special Board: annual, review, special

\section{Association of Thrift Cooperatives}

14. Association's size

10 - 20 TCs within $15 \mathrm{kms}$ radius

15. General Body of Association

Board members of all member-TCs

16. Board of Directors

Presidents of all member-TCs 
17. President

18. Staff

19. Savings Products

20. Loan Products

21. Meetings
Elected by Board Members from among themselves

Internal Auditor and Bookkeeper

Same as member TCs

Three times Compulsory Thrift, Bonus, Life Insurance

General Body: Annual, Ordinary, Special (2 types)

Board: Monthly, Review, Special

\section{Legal Status}

TCs and ATCs are registered under the Andhra Pradesh Mutually Aided Cooperative Societies Act of 1995 (Macs Act of 1995) 
Table 1

Performance of Women's Thrift Cooperatives, 1990 to 2004

Price Adjusted to 2004 Rupees for Years Before 2004. Rs.45=\$1 in 2004

\begin{tabular}{lcrrrrr} 
& & & & & \multicolumn{3}{c}{ 31-Dec-04 } \\
& & 31-Dec-90 & 31-Dec-95 & 31-Dec-00 All Coops & 27 WTCs in Study \\
Members & No & 1,422 & 13,830 & 45,605 & 69,536 & 17,212 \\
Total Funds in Cooperatives & Rs & 233,916 & $14,028,206$ & $74,122,465$ & $158,537,100$ & $58,692,600$ \\
& & & & & & \\
Average Funds per Member & Rs. & 164 & 1,014 & 1,625 & 2,280 & 3,410 \\
Loans Outstanding & No & 980 & 9,764 & 30,502 & 39,275 & 10,750 \\
Loan Amount Outstanding & Rs & 216,400 & $12,513,119$ & $66,034,668$ & $124,094,261$ & $58,692,600$ \\
Average Loan Amount Outstanding & Rs & 221 & 1,282 & 2,165 & 3,160 & 5,065 \\
\% defaults, \# & $\%$ & $0.00 \%$ & $8.90 \%$ & $14.71 \%$ & $11.79 \%$ & $\mathrm{n} / \mathrm{a}$ \\
\% defaults, Rs. & $\%$ & $0.00 \%$ & $1.02 \%$ & $2.11 \%$ & $1.04 \%$ & $\mathrm{n} / \mathrm{a}$
\end{tabular}

Source: CDF Annual Report, 2004; CDF 2005; Economic Survey of India for inflation data 
Table 2a

Joint Liability Group Diversity

Actual Number of Diverse Groups and Average of Randomly Generated Groups

Cooperative

Bheemadevarpalle

Erraballe

Kannaram

Katkur

Kothakonda

Mallaram

Mulkanoor

Mustafapur

Mutharam

Vellore

Bommakal

Chelpur

Dammakapeta

Dharmarajupalle

Huzurabad

Ippanarsingapur

Kandugula

Prataparudra

Singapur

Vidya

Gatlanarsingapu

Gopalpur

Jaganathpur

Jeelgul

Koppur

Kothapalle

Rangayapalli
Total

102

112

77

63

131

114

374

101

56

92

134

150

34

74

238

61

48

295

40

180

142

99

67

76

101

144

59
$\%$ Diverse

\begin{tabular}{cc} 
Actual & Random Average \\
$25 \%$ & $86 \%$ \\
$21 \%$ & $77 \%$ \\
$43 \%$ & $77 \%$ \\
$65 \%$ & $98 \%$ \\
$44 \%$ & $74 \%$ \\
$36 \%$ & $76 \%$ \\
$28 \%$ & $84 \%$ \\
$33 \%$ & $91 \%$ \\
$23 \%$ & $89 \%$ \\
$38 \%$ & $75 \%$ \\
$40 \%$ & $94 \%$ \\
$33 \%$ & $96 \%$ \\
$41 \%$ & $92 \%$ \\
$34 \%$ & $86 \%$ \\
$39 \%$ & $89 \%$ \\
$48 \%$ & $95 \%$ \\
$42 \%$ & $61 \%$ \\
$20 \%$ & $54 \%$ \\
$38 \%$ & $76 \%$ \\
$30 \%$ & $93 \%$ \\
$31 \%$ & $88 \%$ \\
$43 \%$ & $96 \%$ \\
$31 \%$ & $95 \%$ \\
$37 \%$ & $83 \%$ \\
$28 \%$ & $80 \%$ \\
$33 \%$ & $70 \%$ \\
$8 \%$ & $83 \%$ \\
& \\
\hline
\end{tabular}

Source: CDF 2005 
Table 2b

Group Diversity and Significance Tests

\# of WTCs where \# of diverse groups significantly* different than expected through randomization

All types of diversity

$\begin{array}{cccc}\text { Less than } & \text { More than } & \begin{array}{c}\text { Total } \\ \text { expected } \\ \text { expected }\end{array} & \begin{array}{c}\text { Applicable } \\ \text { different }\end{array} \\ \begin{array}{ccc}\text { WTCs } \\ 27\end{array} & 0 & 0 & 27 \\ 23 & 0 & 2 & 25 \\ 2 & 2 & 15 & 19 \\ 9 & 8 & 10 & 27 \\ 0 & 8 & 11 & 19 \\ 25 & 0 & 0 & 25\end{array}$

*Significant at the 0.05 level

Source: CDF 2005 
Table 3a

Village and WTC Membership by Caste

Village Population (2000)

OC/BC SC/ST Total Pop Villages/WTCs

2005 Membership (All 27 WTCs)

$75 \% \quad 25 \% \quad 119,458$

$22^{*}$

$81 \% \quad 19 \% \quad 17,294$

27

* There are three villages/towns with more than one WTC:

Huzurabad has a population of over 35,000 and is served by four WTCs.

Jeelgul and Dharmarajupalle are served by two WTCs each.

Table 3b

SC/ST Representation in Membership of WTCs $^{\wedge}$

Greater than Expected 6

Less than Expected $\quad 15$

Representative $\quad 6$

$\begin{array}{ll}\text { Total } & 27\end{array}$

$\wedge^{\wedge}$ chi-square test of representativeness, with 0.05 p-value Source: CDF 2005 


\section{Table 4}

\section{Caste Composition of Membership, Board, and Presidency, 2001 and 2005}

\begin{tabular}{lcccrc} 
& & & & \multicolumn{2}{c}{ Total Number } \\
\cline { 3 - 6 } 2001 Membership (WTCs with 2001 data) & BC & OC & SC/ST & Individuals WTCs \\
2001 Board (WTCs with 2001 data) & $59 \%$ & $26 \%$ & $14 \%$ & 284 & 24 \\
2001 Presidents (WTCs with 2001 data) & 9 & 14 & 1 & 24 & 24 \\
\hline 2005 Membership (WTCs with 2001 data) & $65 \%$ & $15 \%$ & $20 \%$ & 16,264 & 24 \\
2005 Board (WTCs with 2001 data) & $60 \%$ & $23 \%$ & $17 \%$ & 286 & 24 \\
2005 Presidents (WTCs with 2001 data) & 8 & 13 & 3 & 24 & 24 \\
\hline 2005 Membership (All 27 WTCs) & $65 \%$ & $16 \%$ & $19 \%$ & 17,294 & 27 \\
2005 Board (All 27 WTCs) & $59 \%$ & $25 \%$ & $16 \%$ & 321 & 27 \\
2005 Presidents (All 27 WTCs) & 8 & 16 & 3 & 27 & 27
\end{tabular}

Source: Cooperative Development Foundation, 2001 and 2005 
Table 5

\section{Savings and Loans By Caste}

Average Loan Balance

OC BC

Average Savings Balance

$5,354 \quad 5,22$

SC ST Total

Average Savings Balance of Borrowers

2,287

2,203

4,390

3,639

5,065

Average Number of Days Membership

3,024

2,893

1,915

1,397

2,147

Average Loan to Savings Ratios (Borrowers Only)

2,269

2,401

2,484

2,105

2,826

1.77

1.80

2,132

1,676

2,317

All monetary figures in Rupees

Source: CDF 2005 